Part of Bureau of Standards Journal of Research, vol. 12, June 1934

\title{
PREECE TEST (COPPER-SULPHATE DIP) FOR ZINC COATINGS
}

\author{
E. C. Groesbeck and H. H. Walkup
}

\section{ABSTRACT}

The Preece test is in common use for inspection purposes to determine the uniformity of galvanized coatings, even though the results are sometimes erratic. An experimental study made with wires with different types of zinc coating and with wires consisting of commercially pure zinc and iron indicates that the $\mathrm{pH}$ value of the copper sulphate solution, the rate of solution of the zinc coating, and the cleanness of the test specimens are important factors in the Preece test. The use of cupric hydroxide instead of cupric oxide for neutralizing the copper sulphate solution is recommended, since a stable $\mathrm{pH}$ is much more quickly reached by its use. Electroplated and sprayed zinc coatings dissolve more rapidly in the copper sulphate solution than do hot-dipped or galvannealed coatings. Pure zinc coatings showed, during their solution, a "potential minimum" (with respect to a copper wire) which was practicaliy absent with coatings that contain iron, such as on galvannealed wires and the inner layer of hot-dipped galvanized wires. This minimum may be caused by the delayed coagulation of basic zinc compounds which coagulation may be accelerated by the presence of iron. The causes and remedies of premature and delayed endpoints are explained. A method for measuring the thickness-distribution of the zinc coating by the use of a suitably acidified copper sulphate solution is suggested.

\section{CONTENTS}

I. Introduction $\ldots$

II. Preece test.

1. Regular procedure

2. Difficulties encountered

3. Principle of the method

III. Experiments

1. Materials used

2. Factors that may affect the results

(a) Rate of solution of the coating

(1) Composition of copper sulphate solution

(2) Temperature

(3) Stirring $\ldots$

(4) Coating tested

Preparation

Composition and structure....

(b) Premature endpoints

(1) Plastic films

(2) Potential measurements

(3) Oxygen concentration cells.......... 798

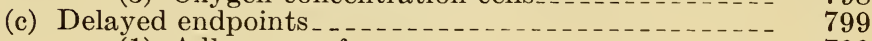

(1) Adherence of copper. 799

Effects of time and $\mathrm{pH}_{\ldots} \ldots$

Effects of composition and temperature

Use of bare steel as endpoint

(d) Distribution of thickness 


\section{INTRODUCTION}

Zinc coatings find wide use for protecting iron and steel against corrosion, because zinc is more readily corroded than iron when they form a "couple" or electrolytic cell in the presence of a conducting liquid. In such a cell the zinc is the anode or dissolving electrode. Since this method of protection depends upon the protective value of the gradual corrosion of the zinc the protective value of the zinc coating depends primarily on its thickness at the thinnest spot.

The total weight or average thickness of a zinc coating is determined by some sort of a stripping method. A common stripping method consists in the removal of the coating by hydrochloric acid containing antimony chloride. If a determination of the distribution of the coating and its minimum thickness is desired, use may be made of a solution that will dissolve the zinc coating at a uniform rate and will reveal the base metal (iron) as soon as it is exposed. A copper sulphate solution of definite concentration is widely used commercially for this purpose in the procedure known as the "Preece test" (1). ${ }^{1}$ Although this test is useful, experience has shown that the results are not always reproducible and consistent, (2), (3), (4), (5), especially when different types of zinc coatings are tested.

The experiments reported in this paper were made to determine relationships rather than to secure absolute data. This policy was prompted by a desire to establish the cause and possible remedies for the observed difficulties rather than the degree of error produced by any one variable.

\section{PREECE TEST}

\section{REGULAR PROCEDURE}

The Preece test is applied by dipping the zinc-coated article, which has previously been cleaned from grease or other foreign material, into a "neutral" solution of copper sulphate of a specified concentration (1.27 mole). This concentration is usually defined by its specific gravity (1.186 at $18 \mathrm{C}$ ), and the solution is maintained at a temperature of $18 \mathrm{C}$ during the test.(6) The sample is immersed in the solution for 1 minute, removed, washed in running water, and freed from the loosely precipitated copper by light rubbing. The 1-minute immersions and cleanings are repeated until an endpoint is obtained in the form of a bright adherent deposit of copper. This indicates that the iron has been exposed there. The number of immersions (dips) reported for each sample is one less than that required for the appearance of adherent copper.

The use of this test in specifications rests on three assumptions: (a) The zinc coating dissolves at a uniform rate; (b) adherent copper is deposited as soon as the underlying iron is exposed; and (c) no adherent copper appears until the zinc coating is entirely removed at that point. Under such conditions the ability to withstand a specified number of immersions is evidence that the zinc coating possesses a certain minimum thickness.

\footnotetext{
1 Figures in parentheses here and throughout the text refer to the numbers used in the list of references at the end of this publication.
} 


\section{DIFFICULTIES ENCOUNTERED}

Practically, these criteria are approximately met by pure zinc coatings, such as those produced by plating, and fairly well by hotdipped galvanized coatings. However, with coatings produced by "galvannealing" ${ }^{2}$ or by sherardizing ${ }^{3}$ the results are less consistent and are not always proportional to the thickness of the coatings. Such discrepancies may be the result of (a) differences in the rate of solution of the zinc coatings, (b) the formation of adherent copper before the zinc coating is all dissolved at that point-that is, a premature endpoint, or (c) the absence of adherent copper on iron that is exposed-that is, a delayed endpoint.

\section{PRINCIPLE OF THE METHOD}

At first glance, it may appear that the method depends merely on the displacement of copper by zinc, according to the reaction.

$$
[1] \mathrm{Zn}+\mathrm{CuSO}_{4}=\mathrm{Cu}+\mathrm{ZnSO}_{4}
$$

This reaction, however, does not account for the deposition of adherent copper on the exposed iron rather than on the undissolved zinc.

It is much more probable that the reaction is electrolytic-that is, solution of zinc occurs at one point comprising an anode, with the deposition of copper at another point serving as a cathode. The cell may then be written:

\section{[2] $\mathrm{Zn}$ (anode) $\left|\mathrm{CuSO}_{4}\right| \mathrm{Cu}$ (cathode) or [3] $\mathrm{Zn}\left|\mathrm{Cu}^{++}\right| \mathrm{Cu}$}

This formula represents the system before any reaction occurs. However, after any finite period some zinc is in the solution adjacent to the zinc surface, and the cell is then represented by

$$
\text { or [5] } \mathrm{Zn}\left|\mathrm{ZnSO}_{4}^{++}\right| \mathrm{CuSO}_{4} \mid \mathrm{Cu}
$$

In any case, the chemical reaction is

$$
\text { [6] } \mathrm{Zn}+\mathrm{Cu}^{++}=\mathrm{Zn}^{++}+\mathrm{Cu}
$$

To produce an electrolytic action, there must be a difference in potential between the two points which become, respectively, anode and cathode. This difference may arise from various causes and differences in the composition or temperature of the adjacent solution. According to this theory, a homogeneous piece of pure zinc will not react with a homogeneous solution of copper sulphate (just as very pure zinc dissolves very slowly in pure sulphuric acid).

The fact that a portion of a zinc specimen or of the zinc coating on steel does replace copper from a copper sulphate solution at once upon immersion is evidence that small areas of the zinc have slightly more positive single potentials than other areas, which latter serve as cathodes upon which the copper is deposited by the dissolving of the adjacent anodic areas. As soon as any copper is deposited, however, it serves as a cathode to the adjacent zinc, and the latter

${ }^{2} \mathrm{~A}$ proprietary process, in which the article (usually wire) is first coated with zinc by hot-dipping and is then heated.

${ }^{3} \mathrm{~A}$ zinc cementation process, in which the article is coated by heating in contact with powdered zinc. 
dissolves with an accompanying precipitation of copper on the already deposited copper. This copper is nonadherent, since the surrounding and underlying zinc is continually dissolving. When a zinc coating on iron is completely dissolved at any point and the underlying iron is thereby exposed, the latter serves as a cathode to the surrounding zinc. An adherent deposit of copper is produced and constitutes the true endpoint. It should be noted that the production of adherent copper on the iron requires the presence of zinc adjacent to it. If a clean piece of iron is dipped into a neutral copper sulphate solution, the deposited copper is not very adherent, though usually more so than is copper deposited directly on zinc.

\section{EXPERIMENTS}

\section{MATERIALS USED}

Although committee A-5 of the American Society for Testing Materials expressed the opinion that the Preece test is unreliable and should be abandoned as a basis of specifications for galvanized sheet and plate, it admitted that this test is a quick and simple method for inspecting galvanized wire, for which it gives comparable results if properly applied (4). Since galvanized wire and wire products are important, wires with various types of zinc coatings were used in this study.

Wires coated with zinc by the hot-dip galvanizing, galvannealing, and electroplating (electrogalvanizing) processes were obtained from certain manufacturers. Two lots of hot-dipped galvanized wire from different sources (designated as $c$ and $k$ ) were used. The electroplated wires were plated in a highly acid bath at a highcurrent density (about 750 amperes per square foot) with insoluble anodes. Wires were coated with zinc by metal spraying in the laboratory. As sherardizing is not commercially applied to wire, this type of coating was not included. Soft steel and commercially pure iron and zinc in wire form were used in the study of the effects of certain factors. The history of the iron, steel, and zinc wires is not known. The test specimens were generally about 3 inches $(7.5$ $\mathrm{cm})$ long and $1 / 8$ inch $(3 \mathrm{~mm})$ in diameter.

The term "Preece solution" used throughout the text refers to a copper sulphate solution of the concentration specified by the American Society for Testing Materials (6) regardless of its other characteristics, such as $\mathrm{pH}$.

\section{FACTORS THAT MAY AFFECT THE RESULTS}

With the above theory as a basis, an effort was made to predict and to test the major effects of variations in operating conditions upon the time of formation, physical properties, and adherence on steel of the precipitated copper.

\section{(a) RATE OF SOLUTION OF THE ZINC COATING}

The use of the Preece test is generally based upon the assumption that the rate of solution of the zinc in various galvanized materials is practically the same. But this rate of solution depends upon 1 , the composition of the copper sulphate solution; 2 , its tempera - 
ture; 3 , the stirring; and 4, the composition and structure of the zinc coating, including any surface films that may be present initially or that formed during the reaction.

\section{(1) COMPOSITION OF COPPER SULPHATE SOLUTION}

The solution generally employed has a specific gravity of 1.186 at $18 \mathrm{C} \mathrm{(6),} \mathrm{which} \mathrm{corresponds} \mathrm{to} \mathrm{a} \mathrm{concentration} \mathrm{of} 1.27$ mole or $315 \mathrm{~g} / \mathrm{l}$ of $\mathrm{CuSO}_{4} \cdot 5 \mathrm{H}_{2} \mathrm{O}$. Although this concentration is artibrary, it is not very critical, and hence no exhaustive tests were made on the effect of concentration on the rate of solution of the zinc. In general, an increase in copper content accelerates the solution of the zinc, and vice versa. The practical significance of this effect is that only a limited amount of a zinc coating should be tested in a given volume of copper sulphate solution, because the precipitation of copper reduces the concentration of copper sulphate.

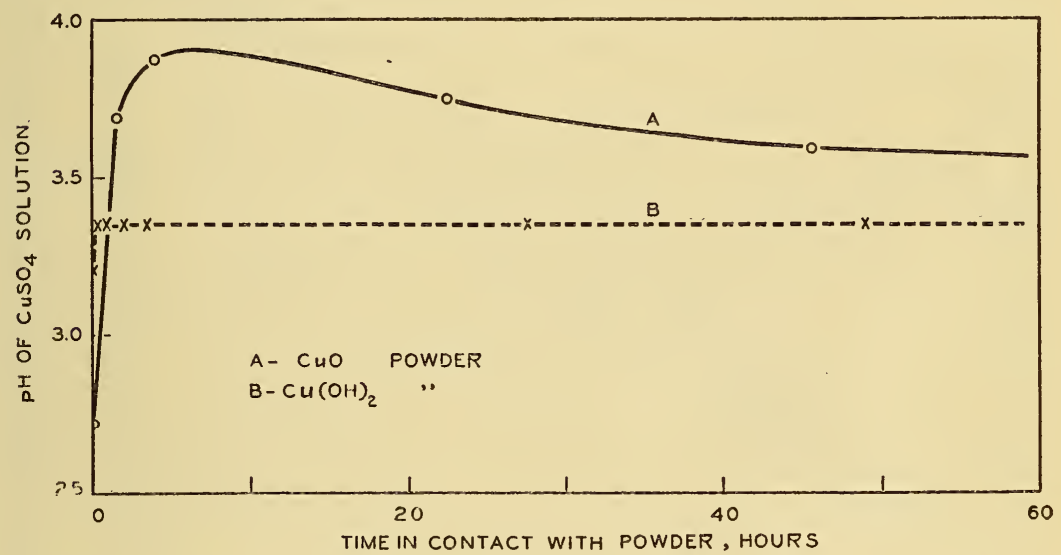

Figure 1.-Change in $\mathrm{pH}$ value of the Preece solution with different neutralizing agents on standing.

The neutralizing agents were added to portions of an unneutralized Preece test solution and the $\mathrm{pH}$ value was determined at intervals.

The neutral solution specified in the test is generally obtained by treating the solution of the salt with an excess of cupric exide at room temperature. Small variations in acidity are most conveniently expressed in terms of hydrogen-ion concentration or $\mathrm{pH}$. A neutral solution of copper sulphate is "acid" because of hydrolysis-that is, it has a pH less than 7 , the neutral point of water. No published data could be found on the exact $\mathrm{pH}$ of copper sulphate solutions of about the concentration used in this work. However, the results of numerous measurements made with a quinhydrone electrode show that the equilibrium $\mathrm{pH}$ is about 3.3 , which defines a truly neutral solution of copper sulphate.

The addition of finely divided cupric oxide to a copper sulphate solution with a $\mathrm{pH}$ of about 2.7 was found to raise the $\mathrm{pH}$ to nearly 4 in a short time (fig. 1). The $\mathrm{pH}$ then decreased to 3.3 on long standing ( 6 weeks) and an insoluble substance, believed to contain basic cupric sulphates (7), (8), was precipitated. It is evident that the final $\mathrm{pH}$ is the result of an equilibrium of sulphuric acid with 
cupric hydroxide or basic cupric sulphate and not with cupric oxide. It is surprising that cupric oxide, which is not easily soluble, would have "over-neutralized" the solution. The use of basic cupric carbonate in place of cupric oxide gave similar results. On the other hand, cupric hydroxide very rapidly produced a $\mathrm{pH}$ value of about 3.3, which remained constant for a long period (fig. 1). The use of either powdered copper hydroxide or basic copper carbonate has been previously recommended for neutralizing purposes.

Since, as will be shown, the $\mathrm{pH}$ of the solution affects the results, it is important to reach the desired $\mathrm{pH}$ quickly and to maintain it during the test. The substitution of cupric hydroxide for cupric oxide

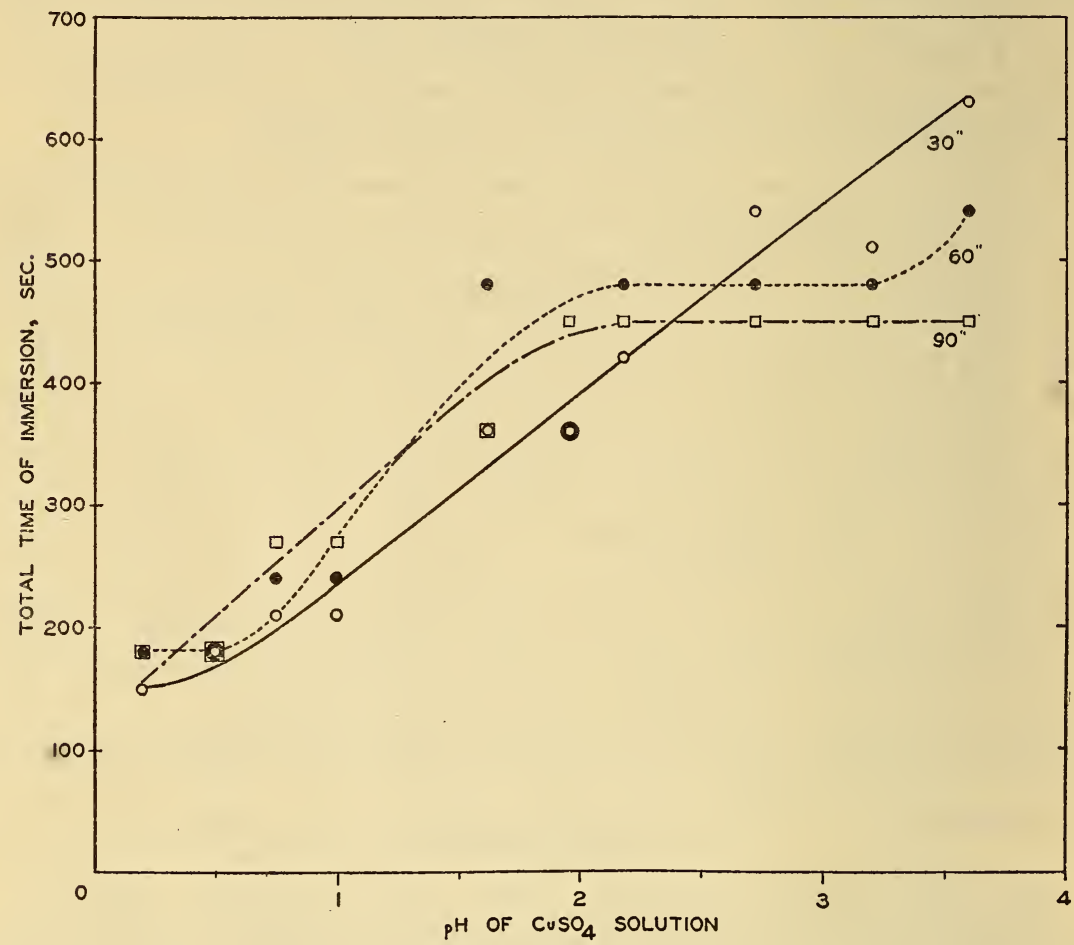

FIGURE 2.-Effect of $\mathrm{pH}$ on the rate of solution of a galvannealed coating.

In each experiment the coated wire was subjected to the Preece solution at about $20 \mathrm{C}$ for successive periods of 30,60 , or 90 seconds, respectively, until a true endpoint was obtained. The $\mathrm{pH}$ of the solution was varied by suitable additions of $\mathrm{H}_{2} \mathrm{SO}_{4}$. The specimens were cleaned with tap water and a dry towel after each immersion.

in neutralizing the solution appears very desirable. As noted above, $\mathrm{pH}$ values greater than 3.3 may be obtained with cupric oxide or carbonate, but such solutions are unstable. For experimental purposes, sulphuric acid may be added to produce $\mathrm{pH}$ values below 3.3 , which can conveniently be measured with a quinhydrone electrode. The rate of solution of the zinc was generally accelerated (fig. 2), by increasing the acidity (decreasing the $\mathrm{pH}$ ) of the solution.

\section{(2) TEMPERATURE}

The rate of solution was found to increase, as expected, with the temperature (fig. 3). The reproducibility of these data does not 
warrant the computation of exact temperature coefficients, but they show that the rate of solution is doubled by an increase of about $15 \mathrm{C}$. This indicates that to obtain an accuracy of about 10 percent in the Preece test it is necessary to keep the temperature constant (for example, at $18 \mathrm{C}$ ) within $2^{\circ}$.

\section{(3) STIRRING}

Moving the specimen, or agitating the solution, has the same effect as increasing the concentration of copper sulphate or of sulphuric acid, because stirring replenishes these compounds close to the metal surface. As it is impracticable to define a rate of agitation, especially for different shapes, it is desirable to avoid any agitation.

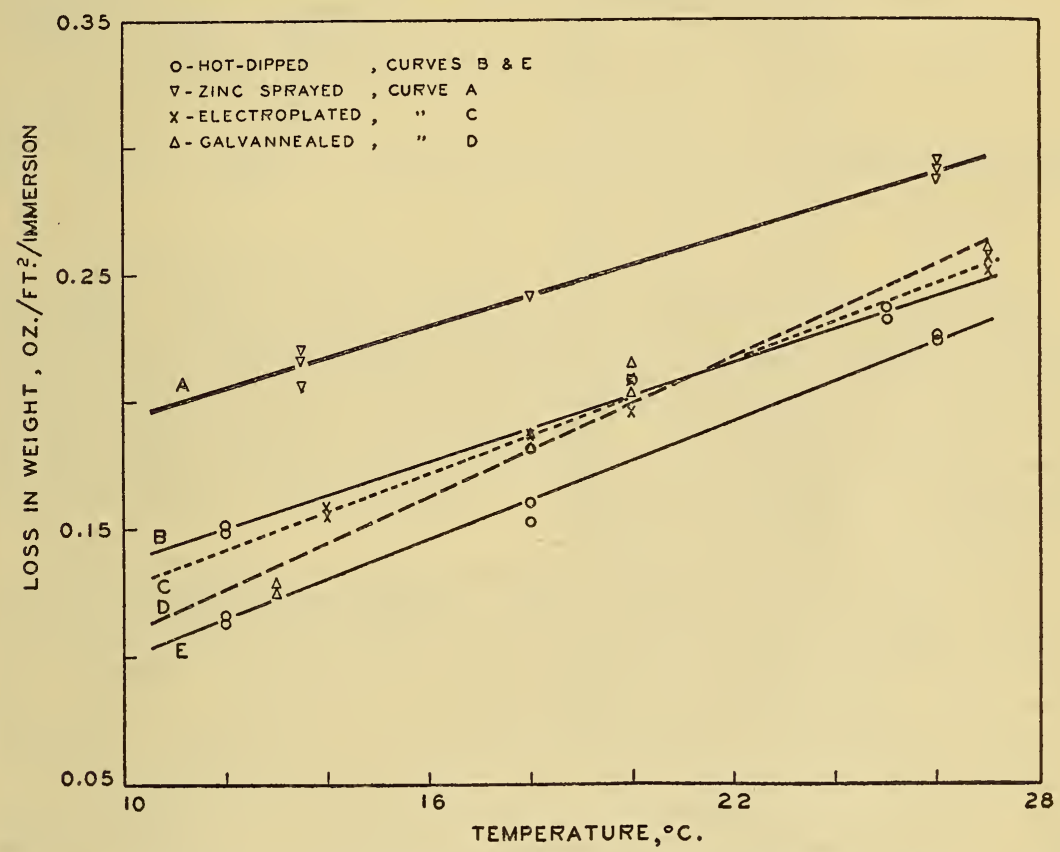

FIGURE 3.-Effect of temperature of solution on average loss in weight for each immersion for different kinds of zinc coatings.

\section{(4) COATING TESTED}

Preparation.-Obviously, any metal coating should be chemically clean when tested for its thickness or behavior. It is also obvious that the method of cleaning should be such that it does not remove any significant amount of the coating. Grease is best removed by an organic solvent, such as benzene, since alkaline solutions may attack the zinc. As it is not practicable to remove any oxide or carbonate films with acid, mechanical cleaning must be used. The data in table 1 indicate the greater rate of solution of zinc from a surface cleaned with fine emery paper (for example, aluminum oxide paper no. 400). The average amount of zinc removed by the emery paper was $0.04 \mathrm{oz} / \mathrm{ft}^{2}$ with a maximum of $0.07 \mathrm{oz} / \mathrm{ft}^{2}$. These losses represent not 
more than 7 percent error in samples with coatings of $1.0 \mathrm{oz} / \mathrm{ft}^{2}$ of the surface, but the error for thinner coatings would be correspondingly larger. It is thus evident that cleaning with even a fine abrasive, such as emery, must be done with great care.

\section{TABLE 1.-Effect of the initial cleaning method on the loss in weight during the first immersion}

[The solution was prepared by dissolving $36 \mathrm{~g} \mathrm{CuSO}_{4} \cdot 5 \mathrm{H}_{2} \mathrm{O}$ to $100 \mathrm{ml} \mathrm{H}_{2} \mathrm{O}$, and adding a slight excess of $\mathrm{Cu}(\mathrm{OH})_{2}$. It was then shaken, let stand for 30 minutes and filtered. The temperature of the solution was approximately $20 \mathrm{C}$, and the immersion periods were 60 seconds]

\begin{tabular}{|c|c|c|c|}
\hline \multirow{2}{*}{ Cleaning method } & \multicolumn{3}{|c|}{$\begin{array}{l}\text { Loss in weight during first } \\
\text { immersion }\end{array}$} \\
\hline & $\begin{array}{l}\text { Electro- } \\
\text { plated } \\
\text { wire }\end{array}$ & $\begin{array}{c}\text { Hot- } \\
\text { dipped } \\
\text { wire }(\mathrm{k}) a\end{array}$ & $\begin{array}{c}\text { Galvan- } \\
\text { nealed } \\
\text { wire }\end{array}$ \\
\hline $\begin{array}{l}\text { Benzene and dry towel } \\
\text { Emery paper and dry towel }\end{array}$ & $\begin{array}{c}O z / f t^{2} \\
0.155 \\
.199\end{array}$ & $\begin{array}{r}O z / f t^{2} \\
0.137 \\
.165\end{array}$ & $\begin{array}{r}O z / f t^{2} \\
0.128 \\
.152\end{array}$ \\
\hline
\end{tabular}

a See sec. III, 1.

Composition and structure.-The various types of zinc coating used in this study vary in both composition and structure. Electroplated coatings consist of practically pure zinc (except when mercury is used in zinc cyanide baths, in which case the deposit may contain up to 1 percent of mercury). The outer surface of hot-dipped coatings consists of nearly pure zinc, while the portion next to the steel is composed of a zinc-iron alloy. A galvannealed coating consists throughout of zinc-iron alloys.

As zinc has a greater solution pressure than iron, it is reasonable to assume that zinc will dissolve more rapidly than a zinc-iron alloy. This is confirmed by the data in table 2, which shows that the rate of solution of the coating and the number of immersions corresponding to a given weight or thickness of zinc are not uniform. Hence, the results for different types of coating are not directly comparable. They may be correlated in either of two ways: 1, by specifying a different number of immersions for a given thickness of each type of coating, or 2 , by changing the immersion period so that the number will be the same for a given thickness. For example, if the period for electroplated coatings were retained at 60 seconds, the other periods would have to be approximately 55 seconds for zinc-sprayed, 80 seconds for hot-dipped, and 120 seconds for galvannealed. These figures are, however, not applicable in a practical way, because the weight of coating dissolved is not exactly proportional to the time. It is much simpler to use 60 -second immersions and to specify the number of immersions that correspond approximately to any desired thickness of a given type of coating.

The initial increase in the solution rate reported for the hot-dipped specimens, followed by a decrease (table 2), is in agreement with Bablik's observation (5) that the solution rate for hot-dipped galvanized sheets increases at first and then decreases with continued immersions. 
TABLE 2.-Loss in weight of commercially pure zinc wire and of different types of zinc coating on iron wires for successive immersions in the Preece solution

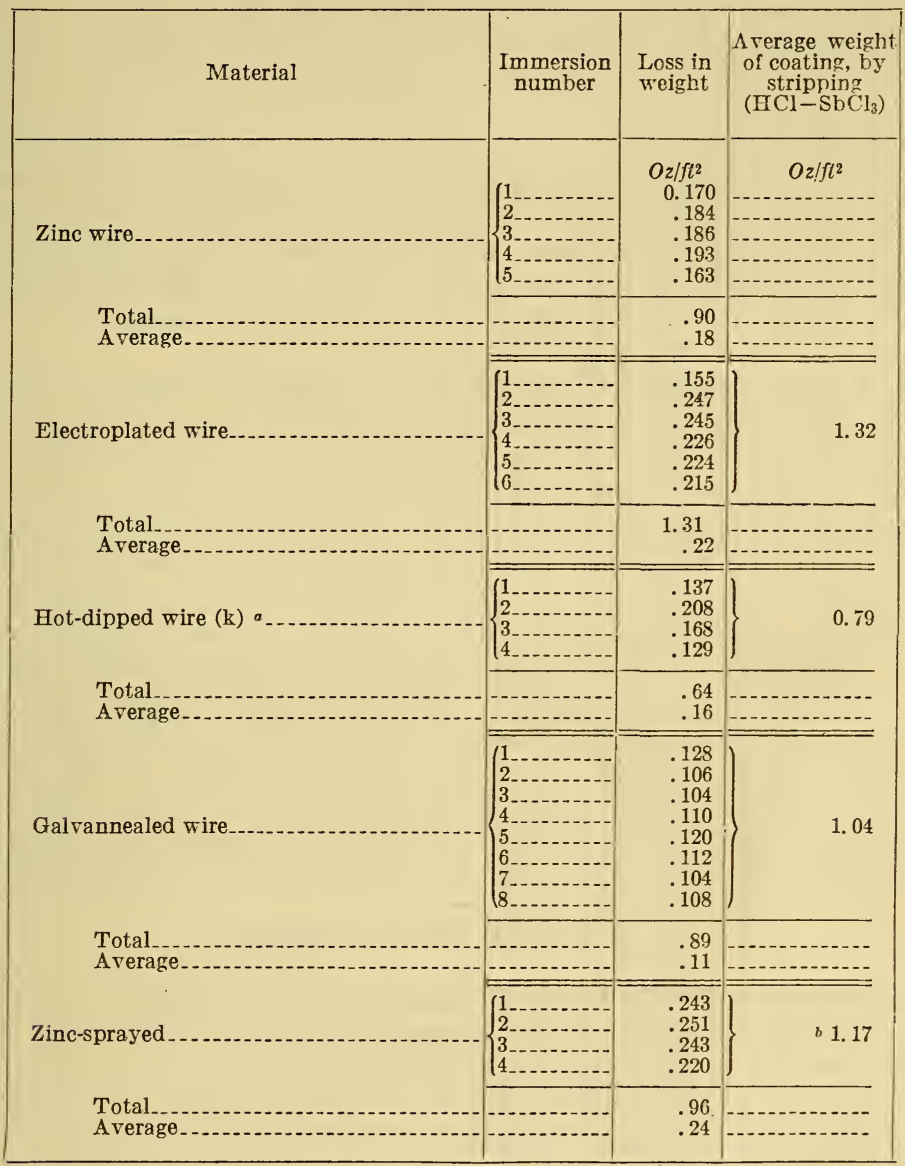

- See sec. III, 1.

$b$ The weight of coating was determined by the difference in weight of the specimens before and after the metal-spraying process. Solution temperature and immersion periods as in table 1.

\section{b. PREMATURE ENDPOINTS}

\section{(1) PLASTIC FILMS}

Data on the rate of solution of zinc coatings are of practical value only if the endpoint can be reliably detected. The appearance of adherent copper on pure zinc coatings is usually definite and reproducible, but adherent copper sometimes appears on hot-dipped or galvannealed coatings before the coating has entirely dissolved underneath the copper deposit.

During cleaning, particles of precipitated copper may adhere to a zinc surface by being squeezed into recesses in a rough surface or into a plastic film, which may be formed during the reaction. The former result is unusual, but may occur if the $\mathrm{pH}$ value is very low (acidic), in which case the zinc is more violently attacked and consequently may be roughened. The occurrence of this latter result is favored by 
conditions which permit the formation of basic precipitates on the zinc surface. The most obvious cause is too high a $\mathrm{pH}$ value of the solution. Under such conditions there will be a tendency for the precipitation of basic compounds from easily hydrolyzable salts. At the cathode of an electrolytic cell, the $\mathrm{pH}$ value tends to increase whenever hydrogen is evolved, a reaction that may occur when zinc is immersed in a copper sulphate solution which necessarily contains hydrogen ions. The hydrogen-ion concentration will also be reduced if any dissolved oxygen is electrolytically reduced on a cathodic area. Exact data are not available to permit the predication of the $\mathrm{pH}$ value at which basic compounds of copper, zinc, and iron may form in these solutions, especially as the respective concentrations of these metals are always changing.

If the copper sulphate is originally 1.27 mole, a complete reaction of this solution with the zinc coating should produce a zinc sulphate solution of the same molar concentration. Actually, some copper sulphate is always present in the solution adjacent to the zinc surface as a result of diffusion and convection. Furthermore, ferrous sulphate may be present in the portion of the solution next to the metal surface if the coating contains iron. The oxidation of the ferrous sulphate to the ferric condition would probably be prevented by the presence of zinc, although it may occur at a short distance from the metal surface. Therefore, the solution next to the metal contains, shortly after the immersion of the zinc-coated specimen, hydrogen, cupric, zinc, ferrous, and possibly ferric, ions. If, now, some of the hydrogen ions are removed, hydroxides (or basic salts) of copper, zinc or iron may be precipitated along with the metallic copper, and may cause the latter to adhere to the surface, even though no steel is exposed.

\section{(2) POTENTIAL MEASUREMENTS}

An effort was made to follow the course of the reaction when a zinccoated specimen is immersed in a copper sulphate solution by making simple potential measurements in a cell consisting of (a) zinc or zinccoated iron wire, (b) copper sulphate solution, and (c) copper wire. The total cell voltage was measured at intervals by means of a high resistance voltmeter.

When a zinc wire or a pure zinc coating (curve A, fig. 4) is immersed in the copper sulphate solution, there is a rapid decrease in potential to a sharp minimum, followed by a relatively slight rise, after which the potential decreases gradually. A potential-minimum was not observed in the case of galvannealed coatings.

There is no completely satisfactory explanation of a curve such as A. The potential measured is that of a primary cell such as the following:

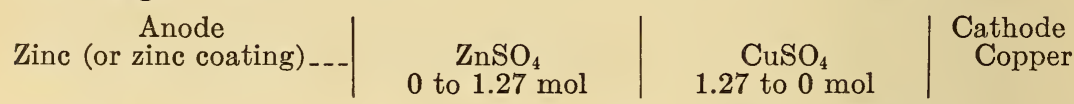

As this cell is discharged, the concentration of zinc sulphate increases and that of copper sulphate decreases. Both of these changes cause a rapid decrease in cell potential, which is represented by the first, i.e., descending, portion of the curve. 
If now the $\mathrm{pH}$ of the solution adjacent to cathodic areas increases, as explained above, there is a tendency for the formation of hydroxides or basic salts. At first these may be in colloidal solution and require a finite time for coagulation. If the latter occurs it would slow up the reaction, retard the precipitation of copper, and permit the original concentrations to be restored by diffusion or convection.

The absence of a potential minimum, when iron is present, may be an evidence that the iron compounds favor coagulation and thus prevent the "supersaturation" with basic compounds.

This explanation is consistent with curve $B$, which shows that the rate of reaction, i.e., the change in potential is at first rapid and then changes at a nearly uniform slower rate.

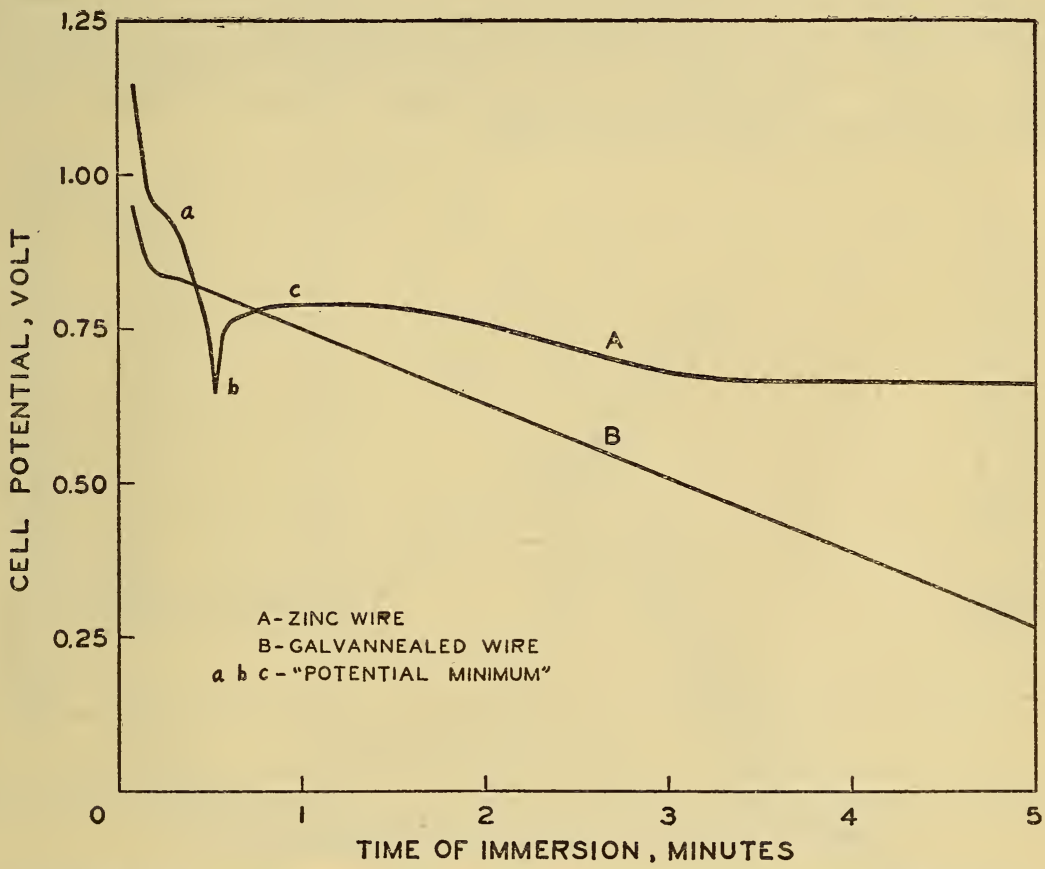

FIGURE 4.-Change in potential with time of immersion for zinc wire and for galvannealed wire.

The curves are representative" of data obtained by using different galvanized and zinc wire specimens as the anode and various $\mathrm{CuSO}_{4}$ solutions as the electrolyte in the cell, specimen / solution / copper wire, with the electrodes placed about $2 \mathrm{~cm}$ apart. A $25,000 \mathrm{ohm}$ voltmeter, provided with a 0 to 2.5 volt scale, and a stopwatch were used.

A somewhat similar curve was obtained by Kreuchen (10) for the potential of a single zinc crystal in normal zinc sulphate solution. He reported that polycrystalline zinc showed a slightly higher potential without any such minimum and attributed the difference to the variation in solution pressure of zinc from a single complete crystal plane and from a broken surface. Such an explanation does not apply to the zinc coatings, which certainly are polycrystalline.

The effects of various factors upon the position of the potential minimum were next investigated. The time required to reach the minimum potential increased as the acidity of the copper sulphate 
solution, which was at about $20 \mathrm{C}$, was increased $(\mathrm{pH}$ was decreasedfig. 5). If, as explained above, the occurrence of the minimum potential is related to the coagulation of hydroxides or basic salts in the copper sulphate solution, a decrease in the $\mathrm{pH}$ of the solution would increase the time needed for this coagulation to take place.

Figure 6 shows the effect of the temperature of the copper sulphate solution on the time required to reach the potential minimum. A satisfactory reason for the marked increase in the time, at 40 to $60 \mathrm{C}$, for zinc, and at lower temperature ranges for hot-dipped and galvannealed coatings, cannot be given, although the shifting of the peak in the curves to the left is apparently related to the iron content of the coating. That the presence of iron in the coating retards or prevents the occurrence of a potential minimum was confirmed by the results obtained (fig. 7) for a hot-dipped galvanized coating, the successive layers of which (starting from the outside) contain increasing proportions of iron. The results for galvannealed wire (curve B, fig. 4) are also in agreement with this conclusion.

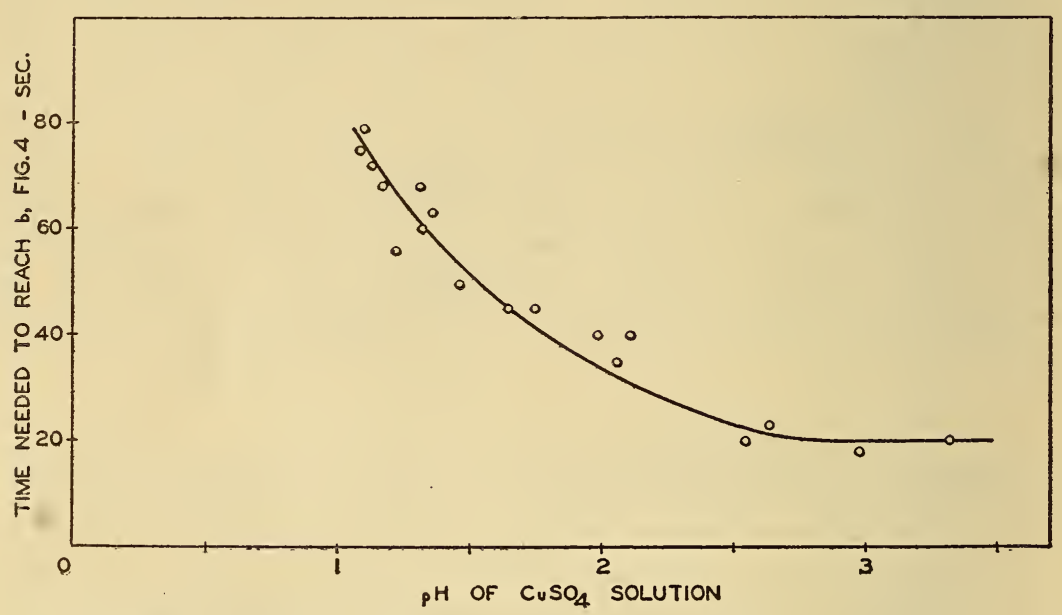

FIGURE 5.-Effect of $\mathrm{pH}$ of solution on the time required to reach the minimum potential (b, fig. 4), when using zinc wire specimens.

If then the basic films form more rapidly on the pure zinc than on the zinc-iron alloy, it is reasonable to suppose that the films formed on the latter would be more adherent and hence be more likely to retain copper particles after the cleaning operation.

That plastic material may be formed on the surface of the coatings, especially of zinc-iron alloys, was shown by numerous observations, summarized $(a, b, c)$, as follows, in which the specimens were washed in running tap water and wiped dry with a towel after immersion in copper sulphate solution.

(a) A pure zinc wire acquired a dull color after a short immersion and a gray color after a period corresponding approximately to the minimum, $\mathrm{b}$, in figure 4 . A longer immersion produced a bright metallic luster, and little or no plastic material could be detected on the surface. 
(b) A plastic film was left on hot-dipped galvanized wires, the amount of which increased with the greater iron content of the lower layers of the coating. wires.

(c) Plastic material was found on the surface of the galvannealed

No potentital minimum was observed when a zinc wire was immersed in a copper sulphate solution containing potassium dichromate, but the surface was coated with a black film. Immersion for a long

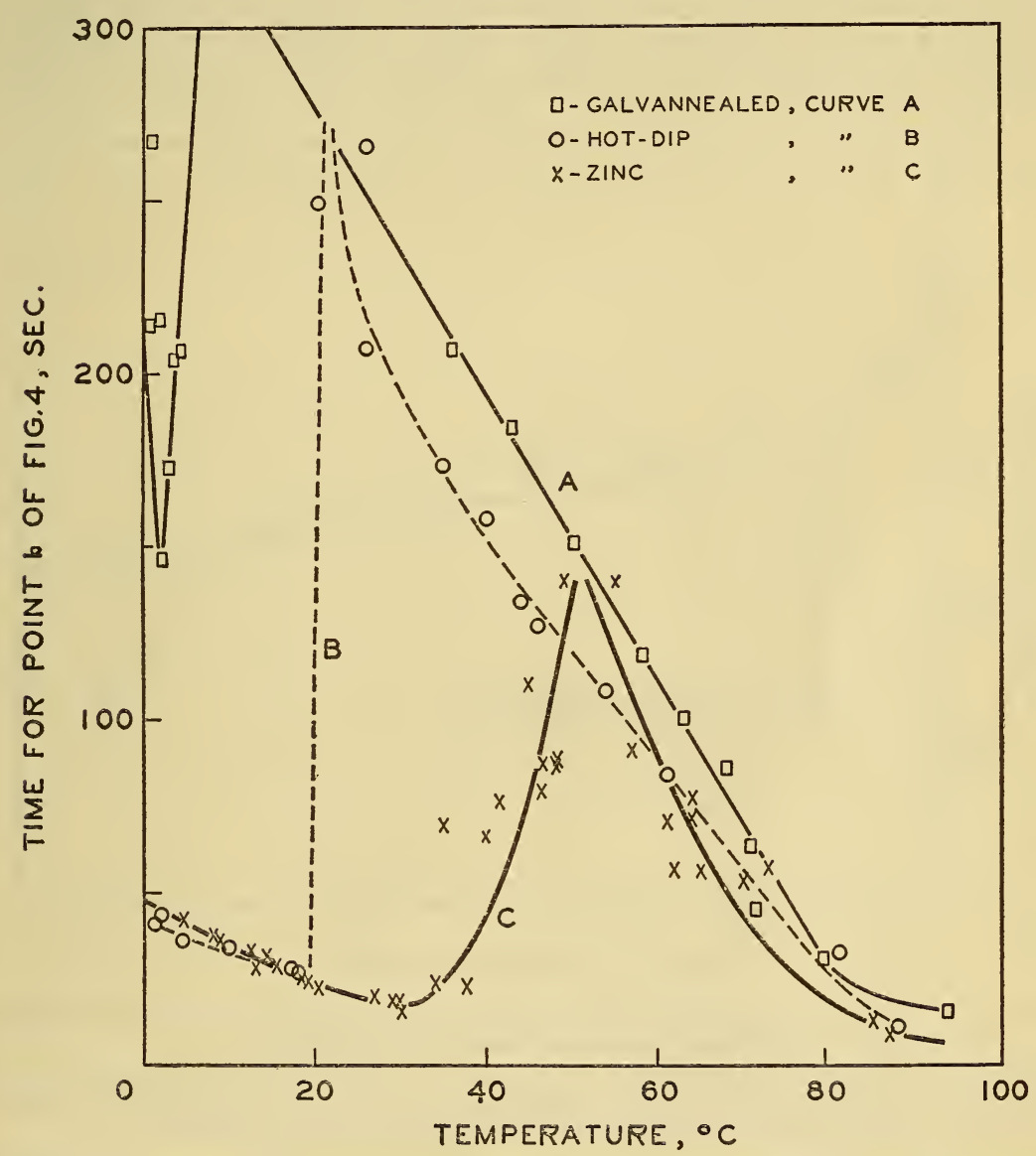

FIGURE 6.-Effect of temperature of the $\mathrm{CuSO}_{4}$ solution on the time required to reach the "potential minimum" (b, fig. 4).

A Preece solution of $\mathrm{pH} 3$ was used.

period produced a plastic residue, which contained a white gelatinous material (presumably basic zinc sulphate), metallic copper, and a black substance (probably containing copper oxide). The dichromate is an oxidizing agent that is readily reduced by zinc, and hence the $\mathrm{pH}$ of the solution was raised to a point where basic compounds were precipitated, as predicted above. It was found that by immersing galvannealed wires in a copper sulphate solution with a $\mathrm{pH}$ between 1 
and 2 for periods of 120 seconds or more the tendency for the production of premature endpoints was decreased.

\section{(3) OXYGEN CONCENTRATION CELLS}

It was predicted that copper may deposit adherently on zinc surfaces if there is sufficient difference of potential to make certain areas cathodic. Such a condition may arise if a portion of the zinc surface is either (a) protected by a film that reduces its solution pressure, or (b) exposed to a copper sulphate solution having a higher oxygen content than that in contact with another portion of the surface. It was found that the first cause can be eliminated by carefully cleaning

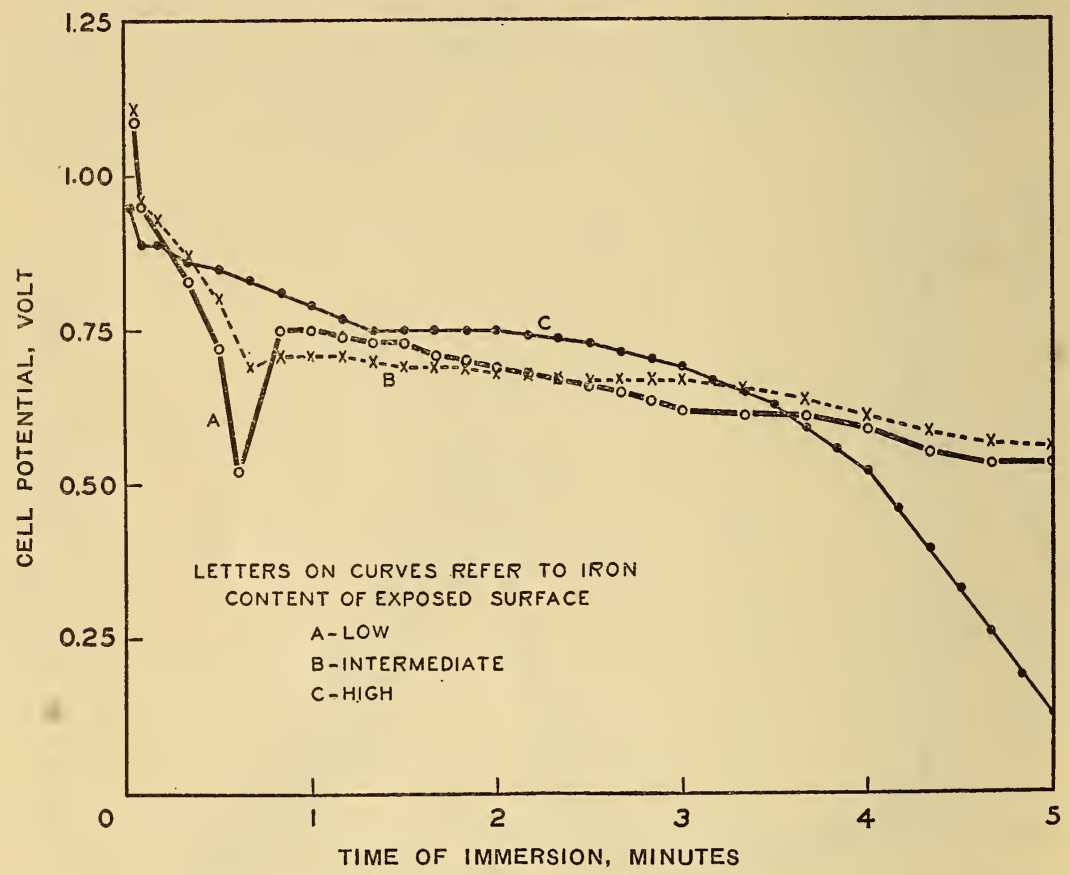

FIGURE 7.-Effect produced by the iron content of the exposed surface of hot-dipped zinc coatings on the potential-time relation.

Specimens of hot-dipped galvanized wire were immersed in a $\mathrm{CuSO}_{4}$ solution for different periods of time and were cleaned by rubbing with a pencil eraser until a bright surface was obtained. They were then immersed in a Preece solution of $\mathrm{pH} 3.2 \mathrm{which}$ was at $10 \mathrm{C}$ for securing the data given.

the specimen before the first immersion and by rubbing it rather firmly between immersions, for example, with a soft pencil eraser.

The effect of an oxygen concentration cell is noticeable near the "water line" of the Preece solution, and it may be accentuated by rotating the partially immersed specimen eccentrically, whereby localized aeration is produced. If this effect is combined with local surface contamination, copper readily deposits on the uncleaned part of the surface. Agitation of the specimen in the Preece test should, therefore, be avoided.

If, for any reason, the zinc dissolves more rapidly at one point than at another, for example, at the water line or near previously exposed steel or abraded areas, copper will deposit on the steel there sooner 
than at other points. Strictly speaking, this latter effect is not a premature endpoint, but is a true criterion of a defective coating. Such defects, if incidental to the preparation or testing of the specimens, should, of course, be disregarded.

\section{(c) DELAYED ENDPOINTS}

\section{(1) ADHERENCE OF COPPER}

Effects of time and $\mathrm{pH}$.- - If, for any reason, copper does not adhere to steel that is exposed in the test the result will be misleading. Because of the difficulty of measuring or expressing the degree of adherence, the following empirical procedure was employed. A copper coating was considered adherent to the steel when it could not be removed by vigorous rubbing with dry cotton or by flaking with the finger nail. Tests were made to determine the length of time specimens could be exposed to the copper sulphate solution before the

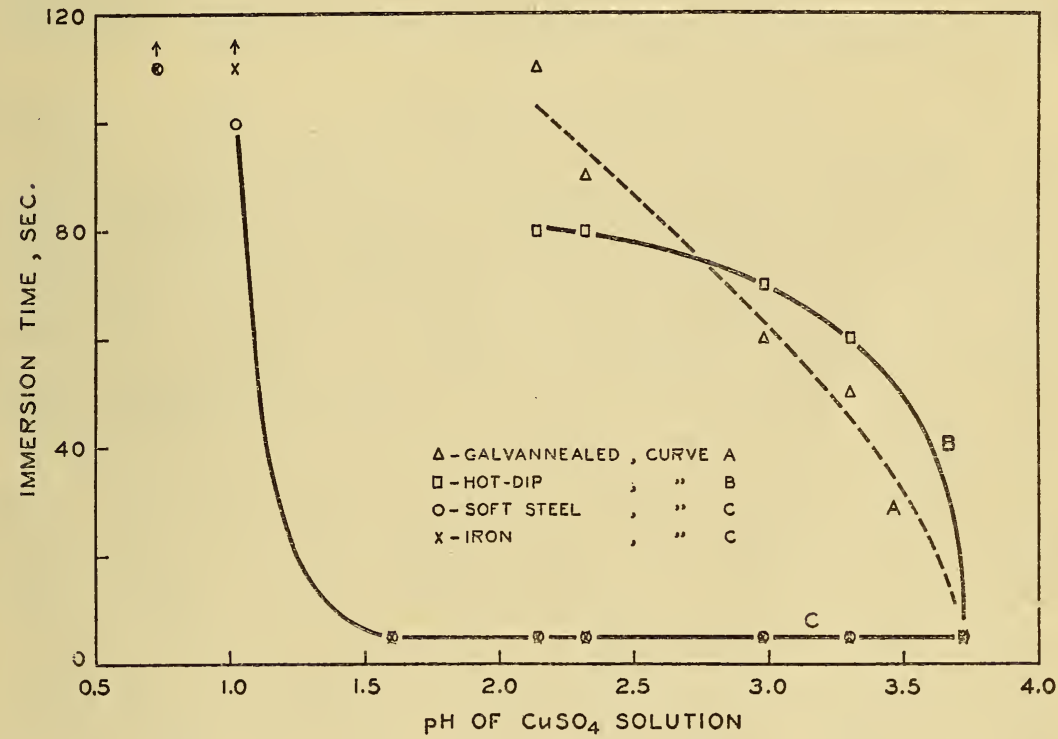

FIgURE 8.-Effect of the $\mathrm{pH}$ value of the $\mathrm{CuSO}_{4}$ solution on the "adherence time" of the copper deposited on iron and steel.

copper deposit became detached from the iron or steel, which had been initially exposed by filing off a portion of the coating.

In the experiments reported in figure 8 , several specimens of the same material were immersed for different periods, each specimen being used only once. The curves present the observed relations rather than the specific data. The specimens were cleaned by first rubbing with aluminum oxide paper no. 400 and then by immersing in a 10 percent $\mathrm{H}_{2} \mathrm{SO}_{4}$ solution for 5 to 10 seconds, followed by washing in water and wiping dry with a cotton swab. Immediately after drying, they were immersed in the $\mathrm{CuSO}_{4}$ solution at $20 \mathrm{C}$. The degree of adherence subsequent to the immersion in $\mathrm{CuSO}_{4}$ solution was approximately defined by the above rubbing and flaking tests.

In all cases the adherence of the copper decreased as the $\mathrm{pH}$ was increased (fig. 8), though it was adherent for approximately 1 
minute when the $\mathrm{pH}$ was 3.3 , the recommended value. On the other hand, the copper deposited on uncoated iron or steel wire was practically nonadherent if the $\mathrm{pH}$ was much above 1 . (This agrees with the general use of an acidified copper sulphate solution to produce copper films on steel by immersion.)

It is of interest to note here that a "contrast in color" method is made use of in a Navy Department specification (11), in which a bright adherent copper deposit on steel is prepared each day of test as a standard color sample for comparison with the color of the copper deposits formed on galvanized wires in the Preece test.

Effects of composition and temperature.-Other tests showed that the adherence of the copper on the galvanized wires was decreased by very small concentrations of chloride or nitrate in the copper sulphate solution. The adherence was increased by cooling the solution, for example, from 30 to $5 \mathrm{C}$. A decrease in concentration of copper sulphate also increased the adherence of the copper. The latter two effects are the results of decreasing the rate of reaction and hence, the rate at which the copper is deposited.

Miscellaneous observations showed that the copper was not as adherent on a perfectly clean steel surface as on a slightly tarnished one. Evidently the clean steel was itself attacked by the solution. When the immersions were continued beyond the usual endpoint, the copper that was at first adherent on zinc-plated specimens became nonadherent, while that on the galvannealed specimens remained adherent. Adherent copper did not always form in the first immersion on the steel bared by filing an electroplated wire, but did in subsequent immersions. If the zinc coating is very uniform so that the entire coating is dissolved in a given immersion (especially the first one), copper does not readily deposit on the steel, even in the succeeding immersion.

Use of bare steel as endpoint.-In view of the uncertainty as to whether or not copper will at once deposit on exposed steel, the appearance of bared steel may sometimes serve as an endpoint, which is usually observed one immersion before the copper would normally deposit. Since the appearance of steel is not so evident as that of adherent copper, it is advisable to give the specimen another immersion to see whether or not the previously exposed steel is coated with adherent copper. In effect, this practice would not differ from the usual procedure, except that the appearance of steel would serve as a warning that the endpoint would probably occur on the next immersion.

\section{(d) DISTRIBUTION OF THICKNESS}

While the Preece test is commonly used merely to detect areas having a minimum thickness, it may be modified so as to give an approximate idea of the thickness distribution. This is accomplished by noting the relative areas coated with copper in immersions succeeding the endpoint. The neutral copper sulphate solution $(\mathrm{pH}-3.3)$ is not satisfactory for this purpose, since exposure to succeeding immersions causes the previously adherent copper to become detached. If, however, sufficient sulphuric acid is added to lower the $\mathrm{pH}$ to about 0.6 , for example, $3 \mathrm{ml}$ of concentrated $\mathrm{H}_{2} \mathrm{SO}_{4}$ to $100 \mathrm{ml}$ of neutral $\mathrm{CuSO}_{4}$, the copper deposit remains adherent throughout the successive immersions. The results (table 3 ) show that in these tests 
the plated and galvannealed coatings were more uniform than the hot-dipped or sprayed ones.

TABLE 3.-Proportion of area covered with adherent copper after successive immersions for 30-second periods

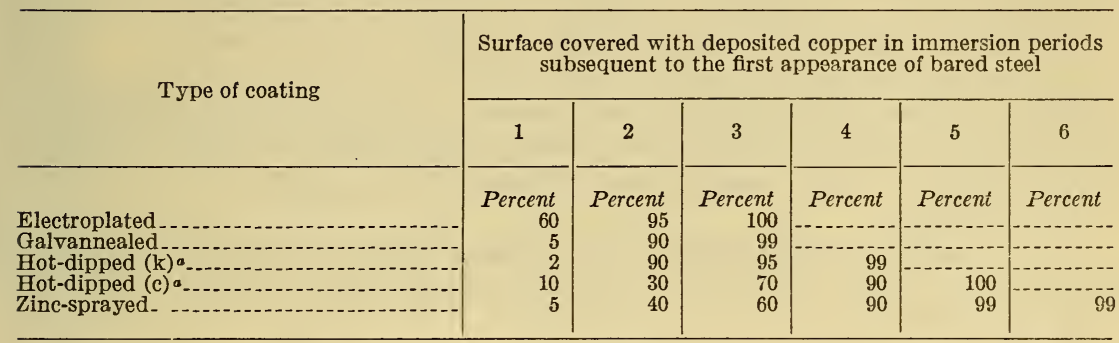

a See sec. 3,1 .

Solution: $3 \mathrm{ml}$ of concentrated $\mathrm{H}_{2} \mathrm{SO}_{4}$ were added to $100 \mathrm{ml}$ of a solution that was prepared in the same way as for table 1 ; temperature of the solution, $18 \mathrm{C}$; concentration, $1.27 \mathrm{~mol}_{-} \mathrm{CuSO}_{4} .5 \mathrm{H}_{2} \mathrm{O}$; and pH, 0.65 .

\section{CONCLUSIONS}

1. If a copper sulphate solution (1.27 mole) is neutralized with cupric oxide, a $\mathrm{pH}$ of 4.0 may be rapidly obtained. On long standing the $\mathrm{pH}$ decreases to about 3.3 , and a basic precipitate forms. A similar result is secured by neutralizing with basic cupric carbonate. Treatment with cupric hydroxide produces inside of 24 hours a solution with a $\mathrm{pH}$ of 3.3 , which is permanent and probably represents the true equilibrium $\mathrm{pH}$. The use of cupric hydroxide as a neutralizing agent is recommended.

2. The specimens to be tested should be thoroughly cleaned before and between immersions (dips), as otherwise adherent copper may form on portions of the zinc surface that are not entirely clean. Grease that is initially present may be removed with an organic solvent, while corrosion products should be carefully removed with a very mild abrasive.

3 . The rate of solution of zinc coatings in copper sulphate solution is increased by raising the concentration of (a) copper sulphate or (b) free acid. Stirring also increases the rate of solution of the coating, and therefore should be avoided in the test. Adherent copper may form on zinc coatings if the wire specimens are rotated eccentrically, which probably produces oxygen concentration cells.

4. Electroplated and sprayed zinc coatings dissolve more rapidly than hot-dipped or galvannealed coatings. For a given thickness of coating, a greater number of 60 -second immersions, or else longer immersions must, therefore, be specified for the latter two coatings.

5 . The potential of zinc, or of a pure zinc coating, in a copper sulphate solution decreases rapidly for about one minute to a potentialminimum, then increases slightly, and finally gradually decreases. No such potential minimum is observed with galvannealed coatings or with the iron-rich layer of hot-dipped coatings. The minimum may be caused by the delayed coagulation of basic zinc compounds. The presence of iron may accelerate this coagulation to form a more dense film, that prevents such a minimum. The position of the potential minimum is affected by the $\mathrm{pH}$ and temperature of the copper sulphate solution. 
6. Premature endpoints, that is, adherence of copper before the underlying steel is exposed, may be caused by the formation of plastic material on the metal surface during the test. This is more likely to occur with zinc coatings containing iron, such as galvannealed coatings or the inner layer of hot-dipped coatings. Its effect can be eliminated by a thorough rubbing of the dried specimen between immersions with a soft abrasive, for example, a pencil eraser.

7. Delayed endpoints may result from the failure of copper to deposit immediately on steel that is exposed. In such cases the appearance of the bare steel may serve as an approximate endpoint, which may usually be confirmed by the deposition of copper in the succeeding immersion.

8. The adherence of copper to the bare steel may be improved by lowering the $\mathrm{pH}$, though it is usually adherent for at least 1 minute when the $\mathrm{pH}$ is 3.3 .

9. By using a more acid solution, for example, $\mathrm{pH}=0.6$, successive immersions after the first appearance of adherent copper may be used to study the thickness distribution of the coating.

\section{SELECTED REFERENCES}

1. M. Pettenkofer, Ueber ein einfacher verfahren, die dicke einer verzinkung auf eisen zu schützen. Múnchen, Natl. Tech. Comm. Abh. I, p. 159, 1857.

2. W. A. Patrick and W. H. Walker, Method for testing galvanized iron to replace the Preece Test. Ind. Eng. Chem. vol. 3, p. 239, 1911.

3. W. M. Peirce, The Preece Test for zinc-coated materials. Iron Age, vol. 114, p. 199, 1924.

4. Report of Committee A-5 on Corrosion of Iron and Steel. Proceedings, Amer. Soc. Testing Matls., vol. 9, p. 100, 1911, and vol. 17, p. 144, 1917.

5. H. Bablik, The Preece Test. Metal Industry (London), vol. 28, p. 369, 1926.

6. Appendix to Standard Methods of determining weight of coating on zinccoated articles: Preece or copper sulphate dip test. Amer. Soc. Testing Matls. Book of A.S.T.M. Standards, part I, p. 323, 1933.

7. S. W. Young and A. E. Stearn, The basic copper sulphates. J. Amer. Chem. Soc., vol. 38, p. 1947, 1916.

8. H. H. Walkup and E. C. Groesbeck, Some factors affecting the Preece Test for zinc coatings. Proc. Amer. Soc. Testing Matls., vol. 32, part II, p. $453,1932$.

9. British Standard Specification for the testing of the zinc coating on galvanized wires, Bull. no. 433, British Standards Institutions, London, 1932.

10. K. H. Kreuchen, Electrolytische untersuchungen an Zinkeinkristallen. Z. Physik. Chem., vol. 155, Abh. A,. p. 161, 1931.

11. United States Navy Department Specification (22-W-10a), dated June' 1, 1932.

Washington, June 8, 1933. 